\title{
Status Karies Gigi pada Pengidap HIV/AIDS
}

\author{
Micahel J. Sundah, Christy N. Mintjelungan, Damajanty H. C. Pangemanan
}

\author{
Program Studi Pendidikan Dokter Gigi Fakultas Kedokteran Universitas Sam Ratulangi \\ Manado \\ Email: jordan.sundah@gmail.com
}

\begin{abstract}
Human immunodeficiency virus (HIV) is a virus that attacks the human immune system, especially white blood cells called CD4 cells. Meanwhile, acquired immune deficiency syndrome (AIDS) is a syndrome that arises due to the decline in the human immune system caused by HIV infection. Several studies showed that people living with HIV/AIDS had a higher risk of developing dental caries compared to those without HIV/AIDS. Maintenance of oral hygiene, consumption of antiretroviral (ARV) drugs, and low salivary flow play a role in increasing the risk of caries in people living with HIV/AIDS. This study was aimed to determine the status of dental caries in people living with HIV/AIDS. This was a literature review using the databases of Google Scholar, PubMed, and Clinical Key. The results obtained five journals that were relevant to the topic of discussion. There was a high prevalence of caries in people with HIV/AIDS $(56.78 \%$ $78.7 \%)$ and a higher average caries status $(12.83 \pm 9.6,15.14 \pm 6.09$, and $11.87 \pm 8.08)$ compared to those without HIV/AIDS. The high prevalence of caries in people with HIV/AIDS was influenced by decreased salivary flow, use of ARVs, consumption of sweet foods, and lack of oral hygiene. In conclusion, the prevalence of caries in people living with HIV/AIDS was high.
\end{abstract}

Keywords: dental caries, HIV/AIDS

\begin{abstract}
Abstrak: Human immunodeficiency virus (HIV) adalah virus yang menyerang sistem kekebalan tubuh manusia kususnya sel darah putih yang disebut sel CD4 sedangkan acquired immune deficiency syndrome (AIDS) merupakan sindrom yang muncul akibat menurunnya sistem kekebalan tubuh manusia yang diakibatkan infeksi HIV. Beberapa penelitian menunjukkan bahwa pengidap HIV/AIDS berisiko lebih tinggi mengalami karies gigi dibandingkan dengan orang tanpa HIV/AIDS. Pemeliharaan kebersihan gigi mulut, konsumsi obat antiretroviral (ARV), dan aliran saliva yang rendah berperan dalam peningkatan risiko karies gigi pada pengidap HIV/AIDS. Penelitian ini bertujuan untuk mengetahui status karies gigi pada pengidap HIV/AIDS. Jenis penelitian ialah suatu literature review. Database yang digunakan untuk pencarian literatur ialah Google Scholar, PubMed, dan Clinical Key. Hasil penelitian mendapatkan prevalensi karies yang tinggi pada pengidap HIV/AIDS (56,78\%-78,7\%) dan rerata status karies lebih tinggi $(12,83 \pm 9,6$, $15,14 \pm 6,09$, dan $11,87 \pm 8,08$ ) dibandingkan dengan yang tanpa HIV/AIDS. Tingginya prevalensi karies pada pengidap HIV/AIDS dipengaruhi oleh penurunan laju aliran saliva, penggunaan ARV, konsumsi makanan manis, dan kurangnya menjaga kebersihan gigi mulut. Simpulan penelitian ini ialah prevalensi karies pada pengidap HIV/AIDS tergolong tinggi.
\end{abstract}

Kata kunci: karies gigi, HIV/AIDS

\section{PENDAHULUAN}

Human immunodeficiency virus (HIV) adalah virus yang menyerang sistem kekebalan tubuh manusia khususnya sel darah putih yang disebut sel CD4. Virus tersebut membawa materi genetik dalam ribonucleic acid (RNA) dan menyerang sel-sel limfosit di dalam tubuh manusia sehingga mengakibatkan sistem kekebalan tubuh menurun. Virus ini dapat masuk ke tubuh manusia melalui perantara darah, semen, dan sekret vagina. Acquired immune deficiency syn- 
drome (AIDS) merupakan sindrom yang muncul akibat menurunya sistem kekebalan tubuh manusia yang diakibatkan infeksi HIV. ${ }^{1-3}$

\section{Data World Health Organization} (WHO) tahun 2019 melaporkan sebanyak 38 juta penduduk dunia hidup dengan HIV. ${ }^{4}$ Profil kesehatan Indonesia menunjukkan jumlah kasus HIV/AIDS di Indonesia pada tahun 2019 sebanyak 50.282 kasus HIV dan 7.036 kasus AIDS. Jumlah kasus terinfeksi HIV paling tinggi ditemukan pada kelompok usia 25-49 tahun. ${ }^{5}$ Kasus HIV di Sulawesi Utara ditemukan pada tahun 1997 dan jumlah kasus terus bertambah. Pengidap HIV/AIDS yang tercatat pada tahun 2019 berjumlah 798 kasus, di antaranya ialah 673 pengidap HIV dan 125 pengidap AIDS. ${ }^{6}$

Pengidap HIV/AIDS juga mengalami masalah gigi dan mulut yang umum seperti karies gigi. Penelitian oleh Kumar et $\mathrm{al}^{7}$ mendapatkan bahwa pengidap HIV/AIDS memiliki risiko lebih tinggi mengalami karies gigi dibandingkan dengan yang tanpa HIV/AIDS. Penurunan sel CD4+ yang terjadi pada pengidap HIV/AIDS dapat menurunkan fungsi kelenjar saliva. Salah satu faktor penyebab terjadinya karies pada pengidap HIV/AIDS ialah terjadinya penurunan fungsi kelenjar saliva antara lain aliran saliva yang rendah. Hal ini dapat menyebabkan peningkatan kolonialisasi bakteri di dalam rongga mulut, terutama bakteri kariogenik karena saliva memiliki fungsi sebagai pembersih rongga mulut dari sisa makanan. Jika aliran saliva rendah, maka fungsi saliva sebagai pembersih akan terganggu dan dapat menyebabkan terjadinya karies. ${ }^{8-10}$

Berdasarkan latar belakang yang telah diuraikan maka penulis tertarik untuk melakukan penelitian tentang status karies gigi pada pengidap HIV/AIDS.

\section{METODE PENELITIAN}

Penelitian ini dilakukan pada bulan Oktober 2020-Januari 2021. Jenis penelitian ini ialah suatu literature review. Pencarian data menggunakan tiga database dengan kriteria yang ditentukan yaitu Pubmed, ClinicalKey dan Google Cendekia. Kata kunci yang digunakan dalam pencarian artikel yaitu caries AND HIV/AIDS. Kriteria inklusi dalam penelitian ini yakni: populasi pengidap HIV/AIDS, tahun publikasi 2011 sampai 2021, serta berbahasa Inggris dan Indonesia. Kriteria ekslusi yakni populasi selain pengidap HIV/AIDS dan artikel yang tidak tersedia fulltext.

\section{HASIL PENELITIAN}

Berdasarkan hasil pencarian literatur, didapatkan artikel sebanyak 235 menggunakan PubMed, 539 menggunakan Clinical Key, dan 2800 menggunakan Google Scholar $(\mathrm{n}=3074)$ yang sesuai dengan kata kunci tersebut. Hasil pencarian yang telah didapatkan kemudian dilakukan skrining berdasarkan judul yang sesuai dengan tema literature review dan diperoleh 12 artikel $(\mathrm{n}=12)$. Selanjutnya 12 artikel tersebut diskrining abstrak dan fulltext berdasarkan kriteria inklusi dan ekslusi dan didapatkan lima artikel $(n=5)$ yang kemudian dijadikan sebagai data penelitian yang membahas tentang status karies pada pengidap HIV/AIDS. Tabel 1 memperlihatkan hasil utama data penelitian dari kelima artikel.

\section{BAHASAN}

Dari kelima literatur yang diperoleh, secara keseluruhan menyatakan bahwa pengidap HIV/AIDS menunjukkan tingkat karies yang tinggi. Kumar et $\mathrm{al}^{7}$ melaporkan dalam penelitiannya bahwa orang dengan HIV-positif memiliki risiko karies gigi yang lebih tinggi dibandingkan dengan yang tanpa HIV. Xerostomia adalah manifestasi umum dari infeksi HIV/AIDS yang terjadi akibat hipofungsi kelenjar saliva akibat infeksi itu sendiri atau obat yang digunakan untuk pengobatan infeksi HIV. ${ }^{15}$ Highly active antiretroviral therapy (HAART) merupakan pendekatan untuk pengobatan HIV/ AIDS yang menghasilkan karies melalui dua jalur berbeda. Pertama, dengan memengaruhi fungsi kelenjar saliva dan menurunkan laju aliran saliva; dan kedua, HAART mengandung konsentrasi glukosa tinggi yang menjadi faktor risiko berkembangnya karies. ${ }^{16}$ 
Tabel 1. Hasil pencarian literatur

\begin{tabular}{|c|c|c|c|c|}
\hline $\begin{array}{c}\text { Peneliti/ } \\
\text { Tahun }\end{array}$ & Judul & Populasi & $\begin{array}{c}\text { Desain } \\
\text { Study/ } \\
\text { instrumen } \\
\text { penelitian }\end{array}$ & Rangkuman Hasil \\
\hline $\begin{array}{l}\text { Kumar et al/ } \\
2014^{7}\end{array}$ & $\begin{array}{l}\text { Oral health status and oromuсо- } \\
\text { sal lesions in patients living } \\
\text { with HIV/AIDS in India: a } \\
\text { comparative study }\end{array}$ & $\begin{array}{l}\text { Penelitian dilakukan pada orang } \\
\text { dengan HIV positif, sampel } \\
\text { pene-litian berusia di atas } 15 \\
\text { tahun }(\mathrm{n}=126) \text { dan orang dengan } \\
\text { HIV negatif }(\mathrm{n}=532) \text {, total } \\
\text { responden }(\mathrm{n}=658)\end{array}$ & $\begin{array}{l}\text { Potong } \\
\text { lintang/ } \\
\text { DMF-T }\end{array}$ & $\begin{array}{l}\text { Skor DMF-T pada } \\
\text { kelompok HIV } \\
\text { positif }(12,83 \pm 9,6) \\
\text { lebih tinggi diban- } \\
\text { dingkan dengan } \\
\text { kelompok HIV } \\
\text { negatif }(8,34 \pm 7.6) \\
\text { dengan } p<0,0001\end{array}$ \\
\hline $\begin{array}{l}\text { Kolisa et } \\
\text { al } / 2019^{11}\end{array}$ & $\begin{array}{l}\text { The burden of oral conditions } \\
\text { among adolescents living } \\
\text { with HIV at clinic in } \\
\text { Johannesburg, South Africa }\end{array}$ & $\begin{array}{l}\text { Penelitian dilakukan pada } \\
\text { pen-derita HIV usia 14-19 } \\
\text { tahun }(\mathrm{n}=407)\end{array}$ & $\begin{array}{l}\text { Potong } \\
\text { lintang/ } \\
\text { DMF-T }\end{array}$ & $\begin{array}{l}\text { Terdapat preva- } \\
\text { lensi karies gigi } \\
\text { sebanyak 56,76\% }\end{array}$ \\
\hline $\begin{array}{l}\text { Souza et } \\
\text { al/ } 2017^{12}\end{array}$ & $\begin{array}{l}\text { Factors associated with } \\
\text { dental caries, periodontitis } \\
\text { and intra-oral lesions in } \\
\text { individuals with HIV/AIDS }\end{array}$ & $\begin{array}{l}\text { Penelitian dilakukan pada } \\
\text { pen-derita HIV/AIDS usia } \\
18-40 \text { tahun }(\mathrm{n}=312)\end{array}$ & $\begin{array}{l}\text { Deskriptif } \\
\text { analitik/ } \\
\text { DMF-T }\end{array}$ & $\begin{array}{l}\text { Prevalensi karies } \\
\text { gigi sebanyak } \\
78,7 \%\end{array}$ \\
\hline $\begin{array}{l}\text { Rezaei- } \\
\text { Soufi et } \\
\text { al/2014 }\end{array}$ & $\begin{array}{l}\text { Dental caries prevalence in } \\
\text { human immunodeficiency } \\
\text { virus infected patients recei- } \\
\text { ving highly active anti- } \\
\text { retroviral therapy in } \\
\text { Kermanshah, Iran }\end{array}$ & $\begin{array}{l}\text { Penelitian dilakukan pada } \\
\text { orang dengan HIV/AIDS usia } \\
26-54 \text { tahun }(\mathrm{n}=100)\end{array}$ & $\begin{array}{l}\text { Potong } \\
\text { lintang/ } \\
\text { DMF-T }\end{array}$ & $\begin{array}{l}\text { Skor DMF-T } \\
15,14 \pm 6,09\end{array}$ \\
\hline $\begin{array}{l}\text { Saravani et } \\
\text { al/2016 }\end{array}$ & $\begin{array}{l}\text { Dental health status of HIV- } \\
\text { positive patients and related } \\
\text { variable in Southeast Iran }\end{array}$ & $\begin{array}{l}\text { Penelitian dilakukan pada } \\
\text { orang dengan HIV positif } \\
(n=119)\end{array}$ & $\begin{array}{l}\text { Potong } \\
\text { lintang/ } \\
\text { DMF-T }\end{array}$ & $\begin{array}{l}\text { Rerata DMF-t } \\
11,87 \pm 8,08\end{array}$ \\
\hline
\end{tabular}

Hasil penelitian Souza et al ${ }^{12}$ melaporkan prevalensi karies yang tinggi pada pengidap HIV/AIDS (78,7\%). Pada 224 responden didapatkan sebanyak $35,27 \%$ yang menunjukkan aliran saliva rendah. Penurunan laju aliran saliva dapat mengurangi fungsi saliva sebagai penetral dan pembersih dalam rongga mulut. Rongga mulut yang kurang bersih dapat mendukung perkembangbiakan bakteri dan mikroorganisme penyebab karies. Keadaan ini dapat meningkatkan risiko terjadinya karies pada pengidap HIV/AIDS. Hal ini sejalan dengan penelitian yang dilakukan oleh Filho dan Giovani ${ }^{17}$ yang melaporkan bahwa penurunan laju aliran saliva yang tinggi dan kapasitas buffer saliva yang rendah dapat meningkatkan risiko karies pada pengidap HIV/AIDS.
Penurunan laju aliran saliva pada pengidap HIV/AIDS juga dipengaruhi oleh penggunaan HAART. Penggunaan HAART dapat menyebabkan penurunan fungsi saliva sebagai kapasitas pembersih dan penetral, menurunkan fungsi elektrolit dan protein dalam saliva yang berfungsi sebagai penghambat pertumbuhan bakteri kariogenik penyebab karies. Hasil penelitian RezaeiSilfa et al $^{13}$ menunjukkan bahwa prevalensi karies gigi dinilai lebih tinggi pada kelompok yang menggunakan pengobatan HAART. Hal yang sejalan juga dilaporkan pada penelitian Kolisa et al ${ }^{11}$ yaitu individu dengan HIV yang menggunakan pengobatan HAART, memiliki prevalensi karies gigi tinggi. Hal ini juga didukung dengan penelitian Nittayananta et $\mathrm{l}^{18}$ dan Bretz et al ${ }^{19}$ yang menunjukkan bahwa terdapat hubung- 
an antara HAART dengan angka karies gigi. Nittayananta et al ${ }^{18}$ menyimpulkan bahwa prevalensi karies gigi lebih tinggi pada pengguna obat antiretroviral jangka panjang. Individu terinfeksi HIV dengan penggunaan HAART memiliki laju aliran saliva lebih rendah yang merupakan faktor peningkatan risiko karies gigi dibandingkan dengan yang terinfeksi HIV tanpa penggunaan HAART. ${ }^{18,19}$

Menurut Saravani et al ${ }^{14}$ terdapat korelasi positif antara durasi HIV dengan indeks DMF-T. Hasil penelitiannya menunjukkan bahwa seiring berkembangnya HIV, jumlah cel CD4 menurun pada individu yang terinfeksi. Penurunan ini mengakibatkan adanya peningkatan karies gigi. ${ }^{18}$ Hasil ini sejalan dengan penelitian Beena ${ }^{20}$ yang mendapatkan prevalensi karies tinggi $(76,47 \%)$ pada pengidap HIV yang mengalami penurunan sel CD4.

\section{SIMPULAN}

Prevalensi karies pada pengidap HIV/ AIDS tergolong tinggi.

\section{Konflik Kepentingan}

Penulis menyatakan tidak terdapat konflik kepentingan dalam studi ini.

\section{DAFTAR PUSTAKA}

1. Hasni S, Teos L, Alevzos I. Clinical Immunology: Principles and Practice (5th ed). Elesevier, 2019; p. 735-42.

2. Hidayat RW. Gambaran karakteristik dan efek samping pengobatan ARV pada anak dengan HIV/AIDS (ADHA) di Yayasan Lentera Surakarta [Skripsi]. Surakarta: STIKES Aisyah; 2019.

3. Harahap A Peran balai rehabilitasi sosial dalam pemberdayaan agama pada penderita HIV/AIDS di Kota Medan [Skripsi]. Medan: Universitas Islam Negeri Sumatera Utara; 2019.

4. World Health Organization. HIV/AIDS: Data and Statistics. Geneva: WHO, 2019.

5. Profil Kesehatan Indonesia Tahun 2019. Jakarta: Kementerian Kesehatan RI, 2020; p.159-60.

6. HIV AIDS. Pusat Data dan Informasi HIV. Jakarta: Kementerian Kesehatan RI, 2020; p. 3-4. Available from: https://pusdatin.ke,kes.go.id

7. Kumar S, Mishra P, Warhekar S, Airen B, Jain

D, Godha S. Oral health and oromucosal lesions in patients living with HIV/ AIDS in India. AIDS Res Treat. 2014: 2014. Article ID 480247. Available from: https://doi.org/10.1155/2014/ 480247.

8. Palupi R, Sosiawan A, Sabdho WGR, Ramadhani A. Factors influencing dental caries in HIV/AIDS patients. Acta Med Philippina. 2019;53(5):412-6.

9. Malhotra A, Ahlawat J, Hegde MN, Mahajan A. Dental caries status in human immunedeficiency virus-positive and acquired immunodeficiency syndrome patients. Indian J Oral Sci. 2016; 7(2):103-6.

10. Hedge MN, Malhotra A, Hegde ND, Sali-vary $\mathrm{pH}$ and buffering capacity in early and late human immunodeficiency virus infection. Dent Res J. 2013;10(6):772.

11. Kolisa YM, Yengopal V, Shumba K, Igumbor J. The burden of oral condi-tions among adolescents living with HIV at clinic in Johannesburg, South Africa. PloS One. 2019;14(10): e0222568.

12. de Souza AJ, Gomes-Filho IS, da Silva CAL, de Santana Passos-Soares J, da Cruz SS, Trindade SC, et al. Factor associated with caries, periodontitis and intra-oral lesions in individuals with HIV/AIDS. AIDS Care. 2018; 30(5):578-85.

13. Rezaei-Soufi L, Davoodi P, Abdolsamadi HR, Jazaeri M, Malekzadeh H. Dental caries prevalence in human immunodeficiency virus infected patients receiving highly active anti-retroviral therapy in Kermanshah, Iran. Cell J. 2014;16(1): 73-8.

14. Saravani S, Zehi TN, Kadeh H, Mir S. Dental health status of HIV-positive patients and related variable in Southeast Iran. Int J High Risk Behav Addict. 2016; 5(2):e29149.

15. Lamanda A, Cheaib Z, Turgud MD, Lussi A. Protein buffering in model systems and in whole human saliva. PLoS One. 2007;2(2):263.

16. Cepeda LAG, Ceballos Salobreña AC, Ortega KL, Arzate-Mora N, Soriano YJ. Oral lesions and immune reconstitution syndrome in HIV+/AIDS patients receiving highly active antiretroviral therapy. Epidemiological evidence. Med Oral Pathol Oral Cir Bucal. 2008; 
13(2):E85-93.

17. Filho JCC, Giovani EM. Xerostomy, dental caries and periodontal disease in HIV+ Patients. Braz J Infect Dis. 2009; 13(1): 13-7.

18. Nittayananta W, Talungchit S, Jaruratanasirikul S, Silpapojakul K, Chayakul P, Nilmanat A, et al. Effects of long-term use of HAART on oral health status of HIV-infected subjects. J Oral Pathol Med. 2011;39(5):397-406.
19. Bretz WA, Flaitz C, Moretti A, Corby P, Schneider LG, Nichols CM. Medication usage and dental caries outcome related variables in HIV/AIDS patients. AIDS Patient Care STDS. 2010; 14(10):549-54.

20. Beena JP. Prevalence of dental caries and its correlation with the immunologic profile in HIV-infected children on antiretroviral therapy. Eur J Paediatr Dent. 2011;12(2):87-90. 